Male Confessions 



\section{Male Confessions}

I N T IMATE REVELATIONSAND

THE RELIGIOUS IMAGINATION

Björn Krondorfer

STANFORD UNIVERSITY PRESS

$S$ T A N F O R D, C A L I F O R N I A 
Stanford University Press

Stanford, California

(C) 2oro by the Board of Trustees of the Leland Stanford Junior University.

All rights reserved.

No part of this book may be reproduced or transmitted in any form or by any means, electronic or mechanical, including photocopying and recording, or in any information storage or retrieval system without the prior written permission of Stanford University Press.

Printed in the United States of America on acid-free, archival-quality paper

Library of Congress Cataloging-in-Publication Data

Krondorfer, Björn.

Male confessions : intimate revelations and the religious imagination / Björn Krondorfer. p. $\mathrm{cm}$.

Includes bibliographical references and index. ISBN 978-0-8047-6899-3 (cloth : alk. paper) -- ISBN 978-0-8047-6900-6 (pbk. : alk. paper) I. Confession in literature. 2. Christian literature--Male authors--History and criticism. 3. Masculinity--Religious aspects--Christianity. I. Title.

PN56.C67K76 2010

$809^{\prime} .933826562--\mathrm{dc} 22$

2009035055

Typeset by Bruce Lundquist in II/I4 Adobe Garamond 
to my daughters Zadekia and Tabitha who, one day, may wonder

if the man they know as their father is the same man who wrote this book 
